\title{
GAMBARAN BULLYING PADA PELAJAR DI KOTA SEMARANG
}

\author{
Erin Ratna Kustanti \\ Fakultas Psikologi Universitas Diponegoro \\ J1. Prof. Soedharto SH Tembalang Semarang 50275 \\ erinratna@undip.ac.id
}

\begin{abstract}
The study was aimed to identify bullying behavior in students from various levels of education. This study presented bullying patterns in every level of education like bullying forms, involvement of other parties (friends and teachers) to bullying behavior. The study was conducted to 567 students (95 elementary school students, 200 junior high school students, 134 senior high school students, and 138 college students) The samples were taken from schools and universities located in Tembalang and Banyumanik Semarang. Samples were determined using stratified random sampling technique. Bullying data was obtained from Bullying Experience for Students Questionnaire. The descriptive analysis result concluded that most of students have experienced bullying. Students who receive the most bullying are elementary school students $(n=78 ; 82.98 \%)$. For elementary school students, unpleasant treatments are most often occurs in the classroom and school yard. In college students, unpleasant treatments are most often occurs in the cafeteria and outside the campus. The higher the education level, the percentage of subjects reporting decreases $(\mathrm{SD}=60.22 \%$; $\mathrm{SMP}=12.36 \%$; $\mathrm{SMA}=6.80 \%$ dan $\mathrm{PT}=$ $5.26 \%$ ). At all levels of education, most subjects did something when bullying happened to their friend. The percentage of subjects who had conducted bullying a friend at various levels of education is quite high. At the high school level, the percentage is highest, reaching $70 \%$.
\end{abstract}

Keywords: bullying, elementary school, junior high school, senior high school, college student, student, Semarang

\begin{abstract}
Abstrak
Penelitian ini bertujuan memetakan perilaku bullying yang dilakukan pelajar di berbagai tingkat pendidikan. Pada penelitian ini akan dilihat pola-pola bullying di setiap tingkat pendidikan, mulai dari bentuk-bentuk bullying yang dilakukan, sejauh mana keterlibatan pihak lain (teman dan guru) dengan perilaku bullying. Penelitian ini dilakukan pada 567 siswa dari berbagai tingkat pendidikan dengan rincian 95 siswa SD, 200 siswa SMP, 134 siswa SMA, dan 138 mahasiswa. Penelitian ini dilakukan pada siswa SD kelas IV-VI, siswa SMP kelas VII-IX, siswa SMA kelas X-XII dan mahasiswa semester I-IV. Sampel penelitian diambil dari sekolah dan perguruan tinggi di wilayah Tembalang dan Banyumanik Semarang. Pemilihan sampel dilakukan dengan teknik stratified random sampling. Data bullying diperoleh dengan menggunakan Kuesioner Pengalaman Bullying Pada Pelajar dan Mahasiswa. Berdasarkan hasil analisis deskriptif dapat disimpulkan bahwa sebagian besar siswa pada semua tingkat pendidikan pernah medapatkan gangguan dari teman. Siswa yang paling banyak mendapat gangguan adalah siswa SD $(n=78 ; 82,98 \%)$. Perlakuan tidak menyenangkan paling sering terjadi di kelas dan halaman sekolah. Pada mahasiswa perlakuan tidak menyenangkan paling sering terjadi di kantin dan di luar kampus. Semakin tinggi tingkat pendidikan prosentase subjek yang melapor semakin menurun (prosentase siswa melapor di tingkat $\mathrm{SD}=60,22 \%$; $\mathrm{SMP}=12,36 \%$; $\mathrm{SMA}=6,80 \%$ dan $\mathrm{PT}=5,26 \%$ ). Pada semua tingkat pendidikan, sebagian besar subjek melakukan sesuatu ketika melihat bullying yang menimpa teman-temannya. Tindakan yang dilakukan yaitu menolong dan membela korban, melerai, menegur, menghentikan, menasihati dan pada siswa SD juga melaporkan peristiwa bullying kepada guru. Prosentase subjek yang pernah menyakiti teman pada berbagai tingkat pendidikan cukup tinggi. Pada tingkat SMA prosentasenya paling tinggi, mencapai $70 \%$.
\end{abstract}

Kata Kunci: bullying, pelajar, SD, SMP, SMA, mahasiswa, Semarang

\section{PENDAHULUAN}

Bullying menjadi permasalahan yang sudah mendunia (Carney \& Marrel, 2001).
Kekerasan atau perilaku bullying diterima ribuan anak dalam setiap harinya (Holt, 2004). Bullying terjadi jika seseorang atau sekelompok orang mengganggu atau 
mengancam keselamatan dan kesehatan seseorang baik secara fisik maupun psikologis, mengancam properti, reputasi, atau penerimaan sosial seseorang serta dilakukan secara berulang dan terus menerus (Bernard \& Milne, 2008). Bullying dapat dilakukan berulang-ulang oleh siswa yang memiliki kekuasaan, terhadap siswa/siswi lain yang lebih lemah, dengan tujuan menyakiti orang tersebut (Black \& Jackson, 2007; Carney \& Marrel, 2001; Craig, Henderson \& Murphy, 2000). Bullying banyak dikaitkan dengan perilaku agresif pada situasi ketika siswa terlihat secara berulang-ulang dalam jangka waktu yang lama melakukan aksi-aksi negatif baik kepada seseorang atau lebih (Olweus, 1993; Fekkes, Pijpers, \& Verloove-Vanhorick, 2005).

Pada dasarnya bullying berbeda dengan perilaku agresif pada umumnya. Karakteristik bullying nampak pada tingkah laku agresif atau kejahatan disengaja, dilakukan berulangkali dalam waktu lama, dan dilakukan pada kondisi interpersonal yang tidak seimbang kekuatannya. (Olweus, 1993). Bullying dapat terjadi secara langsung maupun tidak langsung. Keduanya meliputi bullying yang bersifat fisik yaitu melakukan agresi dengan kontak fisik, agresi verbal baik dengan kata-kata maupun tulisan dan cyberbullying yakni dengan menggunakan perantara media komunikasi seperti internet dan teknologi digital perilakunya (Bernard \& Milne, 2008; Craig, Pepler \& Blais, 2007). Sedangkan Secara operasional (Olweus, 1993) membagi tiga bentuk/tipe dari bullying, yaitu:

a. Direct verbal attack (perlawanan melalui verbal secara langsung), contohnya seperti menggunakan arti kata atau memanggil nama dengan sebutan yang bisa meyakiti).

b. Direct physical attack (perlawanan fisik secara langsung), contohnya seperti menggigit, meninju/ memukul dan menampar.

c. Indirect or social attack (perlawanan tidak langsung atau secara social), yaitu perilaku isolasi atau mengucilkan maupun menolak orang lain dalam suatu kelompok.

Perilaku bullying melibatkan tiga komponen yang saling mempengaruhi, yakni pelaku, korban dan penonton. Ketiganya memberi andil dalam terwujudnya perilaku bullying (Olweus, 1993). Rigby (2002) menjelaskan ciri-ciri pelaku bullying, pelaku umumnya memiliki ukuran fisik yang besar atau memiliki kekuasaan diantara teman-temannya sehingga korban tidak berani untuk melawan atau menghindar, kebanyakan pelaku adalah korban bullying atau kekerasan di rumah. Pola perilaku di rumah ditransformasikan dalam perilaku di sekolah. Pelaku bullying melakukan modeling terhadap perilaku yang dilakukan orangtua yang telah diterimanya. Pelaku bullying memiliki kepedulian yang rendah terhadap teman-temannya, sehingga tidak peka dengan penderitaan yang di alami korban. Pelaku bullying kelihatan pandai meskipun sebenarnya memiliki hambatan dalam permasalahan akademik. Hal ini dilakukan untk menutupi self esteem-nya yang buruk untuk dapat diakui oleh orang lain.

Sedangkan menurut Rigby (2002) korban bullying memiliki karakteristik sebagai berikut:

a) Korban umumnya secara fisik maupun sosial berada pada posisi lemah. Hal ini menyebabkan korban tidak dapat melakukan perlawanan atau menghindari perlakuan yang diterima. Ketidak mampuan korban untuk melawan atau menghindar menjadi penguat bagi pelaku untuk terus dilakukan aksinya. 
b) Korban memiliki tingkat asertivitas yang rendah. Korban tidak berani mengungkapkan ketidaksenangan atas tindakan yang telah diterimanya dan cenderung menuruti semua keinginan pelaku.

c) Korban mengalami penurunan prestasi di sekolah secara drastis. Hal ini disebabkan korban tidak dapat berkonsentrasi dalam belajar karena dibayangi ketakutan akan tindakan yang akan diterimanya.

d) Korban mengalami depresi bahkan pada tingkat yang akut terdorong untuk melakukan bunuh diri.

e) Korban biasanya akan menderita keluhan-keluhan fisik seperti sakit perut, sulit tidur dan terlihat lesu.

f) Korban akan menunjukkan sikap agresif ketika di rumah. Ketidakmampuan mengespresikan kemauannya di sekolah akan ditumpahkan di rumah.

Selain pelaku dan korban, Rigby (2002) menjelaskan ciri-ciri saksi atau penonton dalam perilaku bullying:

a) Penonton kurang memiliki asertivitas dan keberanian sehingga tidak mau menghentikan perilaku bullying atau melapor pada orang yang lebih dewasa. Penonton takut turut menjadi korban jika menghentikan atau melapor. Penonton yang melaporkan akan mendapatkan julukan sebagai informan pihak sekolah.

b) Penonton juga dibayangi oleh perasaan takut jika tindakan bullying itu akan menimpa dirinya di waktu lain. Hal ini juga berdampak menurunnya minat untuk belajar.

c) Penonton justru menjadi pendukung perilaku bullying yang terjadi.

Perilaku bullying berkaitan erat dengan masalah kesehatan baik fisik maupun mental. Penderita bullying lebih sering mengalami sakit kepala, perut, gangguan tidur, mengompol, depresi serta yang terparah adalah adanya kecenderungan untuk bunuh diri. Pelaku bullying juga rentan terhadap gangguan depresi dan gangguan emosional. Ciri-ciri pelaku biasanya agresif, delinkuen dan jahat. Sedangkan korban biasanya memiliki harga diri yang rendah, kurang asertif, cenderung pencemas, menarik diri, Secara fisik lebih kecil dan lebih lemah, dan cenderung memiliki peringkat yang rendah (Fekkes, Pijpers, \& Verloove-Vanhorick, 2005). Berdasarkan hasil penelitian, perilaku bullying di SD akan berlanjut ke sekolah menengah bahkan sampai ke tempat kerja. Bullying biasa terjadi di setiap tingkat pendidikan, baik itu SD, SMP, sekolah tingkat atas dan universitas. Semakin tinggi level pendidikan, perilaku bullying semakin menurun jumlahnya (Nelso \& Israel, 1997).

Penelitian ini bertujuan memetakan perilaku bullying yang dilakukan pelajar di berbagai tingkat pendidikan. Pada penelitian ini dikaji pola-pola bullying di setiap tingkat pendidikan, mulai dari bentuk-bentuk bullying yang dilakukan, dan sejauh mana keterlibatan pihak lain (teman dan guru) dengan perilaku bullying. Adapun rumusan masalah yang diajukan dalam penelitian ini adalah bagaimana pola bullying yang terjadi di jenjang pendidikan SD hingga Perguruan Tinggi di Kota Semarang?

\section{METODE PENELITIAN}

Penelitian ini dilakukan pada 567 subjek dari berbagai tingkat pendidikan dengan rincian 95 siswa SD (kelas IV-VI), 200 siswa SMP (kelas VII-IX), 134 siswa SMA (kelas X-XII) dan 138 mahasiswa (semester I-IV). Populasi dalam penelitian ini adalah pelajar dari tingkat SD sampai perguruan tinggi di kota Semarang. Sampel penelitian diambil dari sekolah dan perguruan tinggi di wilayah Tembalang dan Banyumanik. 
Pemilihan sampel dilakukan dengan teknik stratified random sampling.

Metode pengambilan data dalam penelitian ini menggunakan Kuesioner Pengalaman Bullying pada Pelajar/Mahasiswa (PBP/M) yang diadaptasi dari Astuti (2008). Kuesioner disusun tidak langsung mengarah pada masalah bullying tetapi pertanyaan disusun secara bertahap, mulai dari kondisi sekolah, suasana sekolah kemudian diarahkan ke senioritas dan bullying. Kuesioner terdiri dari beberapa pertanyaan yang mengungkap hal-hal seperti berikut : 1) Situasi yang memicu/penyebab terjadinya bullying, 2) pernah / tidak menjadi korban bullying, 3) pernah/tidak menjadi pelaku bullying, 4) bentuk perilaku bullying, 5) lokasi dan waktu terjadinya bullying, 6) reaksi ketika menjadi korban bullying, 7) reaksi ketika melihat orang lain menjadi korban bullying. Analisis data dilakukan dengan menggunakan analisis statistik deskriptif.

\section{HASIL DAN PEMBAHASAN}

Penelitian ini dilakukan pada siswa di berbagai tingkat pendidikan, mulai dari SD hingga perguruan tinggi. Subjek pada penelitian ini memiliki rentang usia mulai dari 9 tahun sampai 21 tahun. pada tingkat pendidikan SD, subjek berasal dari kelas IV-kelas VI. Pada tingkat pendidikan SMP subjek berasal dari kelas VII- kelas IX, pada tingkat pendidikan SMA subjek berasal dari kelas X-kelas XII dan pada tingkat perguruan tinggi subjek berasal dari mahasiswa semester I-semester IV. Pada penelitian ini subjek menceritakan pengalamannya berkaitan dengan bullying, baik sebagai pelaku, korban ataupun sebagai bystander. Hasil penelitian ini mengungkap bullying yang terjadi pada siswa SD, SMP, SMA dan mahasiswa.

Berdasarkan kuesioner yang telah diberikan diperoleh data tentang pandangan subjek mengenai sekolah/kampusnya berikut dengan suasana dan hal-hal yang mengarah pada munculnya perilaku bullying. Data yang ditampilkan di pembahasan ini hanya yang berhubungan langsung dengan masalah bullying.

Kuesioner pada penelitian ini disusun tidak langsung mengarah pada perilaku bullying tetapi bertahap, dimulai dari situasi/kondisi yang mendorong munculnya bullying. Penjabaran situasi/ kondisi ini dimulai dengan menggambarkan kondisi sekolah/kampus, gambaran hal-hal yang menjadikan siswa merasa takut, sedih, marah, dan tertekan serta gambaran pergaulan dengan teman seangkatan, kakak kelas dan adik kelas.

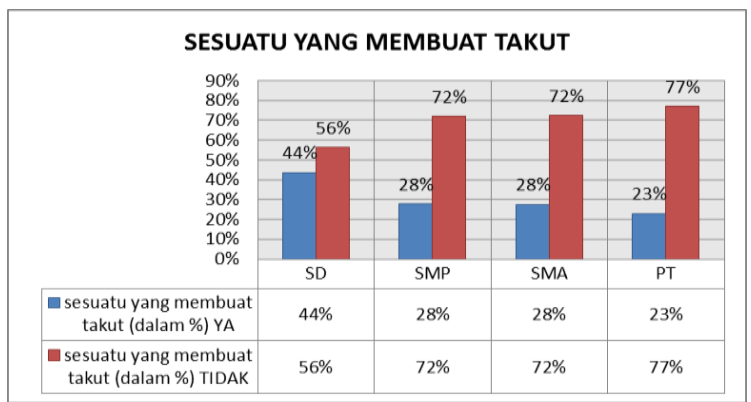

Gambar 1.

Sesuatu yang Membuat Takut

Gambar 1 menunjukkan bahwa prosentase subjek yang merasakan sesuatu yang membuat takut di sekolah paling tinggi berada pada tingkat SD yang mencapai 44\%. Pada siswa SD hal-hal yang menimbulkan perasaan takut adalah guru yang galak, kakak kelas yang jahat dan dipukul teman. Pada siswa SMP dan SMA hal-hal yang menakutkan adalah guru yang galak, nilai jelek, kakak kelas yang jahat, memiliki musuh, digosipkan, teman yang suka mengejek dan bertengkar dengan teman. Sedangkan pada mahasiswa hal-hal yang menimbulkan perasaan takut berkaitan dengan kegiatan perkuliahan dan dosen.

Gambar 2 menunjukkan data tentang sesuatu yang membuat sedih di 
sekolah/kampus. Berdasarkan data penelitian dapat disimpulkan bahwa prosentase subjek yang merasakan sesuatu yang membuat sedih di sekolah paling tinggi berada pada tingkat SD yang mencapai $42 \%$. Pada siswa SD sesuatu yang menjadikan sedih adalah dibenci/tidak punya teman, dipalak, dimusuhi, dikunci di kamar mandi, dicuri uangnya, dipukul, diejek, diancam dan orangtua yang diejek. Pada siswa SMP hal yang membuat sedih adalah diganggu, difitnah, dimusuhi, diejek. Pada siswa SMA ditinggal/dijauhi teman dan sikap teman yang suka pilih-pilih siapa yang menjadi peer-groupnya merupakan hal-hal yang membuat sedih. Pada mahasiswa juga tidak jauh berbeda dengan siswa SMA, masalah peer group dan kesenjangan sosial menjadi hal yang membuat sedih di kalangan mahasiswa.

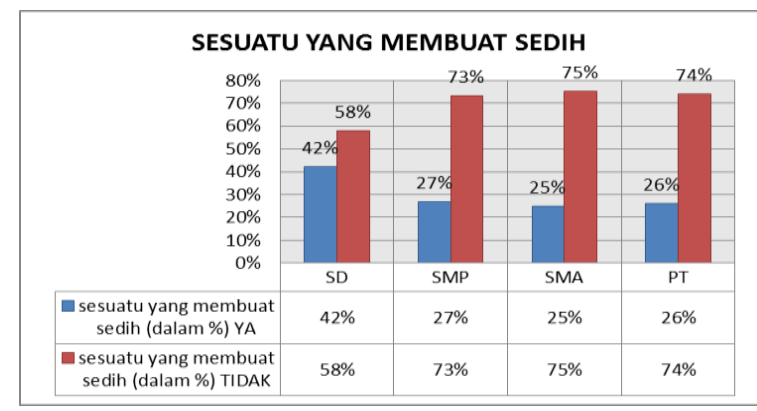

Gambar 2.

Sesuatu yang Membuat Sedih

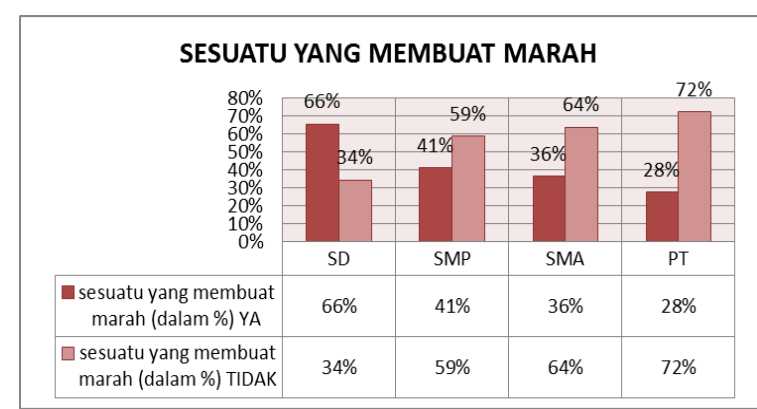

Gambar 3.

Sesuatu yang Membuat Marah

Pertanyaan selanjutnya tentang hal-hal yang membuat marah di sekolah/kampus. Berdasarkan data pada Gambar 3 dapat disimpulkan bahwa diantara berbagai tingkat pendidikan, hal-hal yang membuat marah paling tinggi terjadi pada subjek yang duduk di bangku SD dengan prosentase lebih dari $60 \%$. Sedangkan pada tingkat pendidikan yang lebih tinggi, prosentasenya semakin menurun. Pada siswa SD, hal-hal yang membuat marah yaitu diganggu, difitnah, diremehkan dan orangtua yang diejek. Pada siswa SMP diganggu saat pelajaran, dijahilin dan privasi yang dilanggar menjadi sesuatu yang menimbulkan kemarahan. Pada siswa SMA hal-hal yang membuat marah diantaranya direndahkan, difitnah, teman yang egois dan pilih-pilih teman. Pada mahasiswa konflik, diremehkan dan teman yang sulit diajak kerjasama merupakan halhal yang menimbulkan kemarahan. Berkaitan dengan perasaan tertekan, dapat disimpulkan bahwa pada setiap tingkat pendidikan hampir semua subjek tidak merasakan perasaan tertekan. Prosentase subjek yang meng-alami perasaan tertekan sangat rendah, berkisar 5\% sampai 20\%, dengan prosentase tertinggi pada tingkat SD.

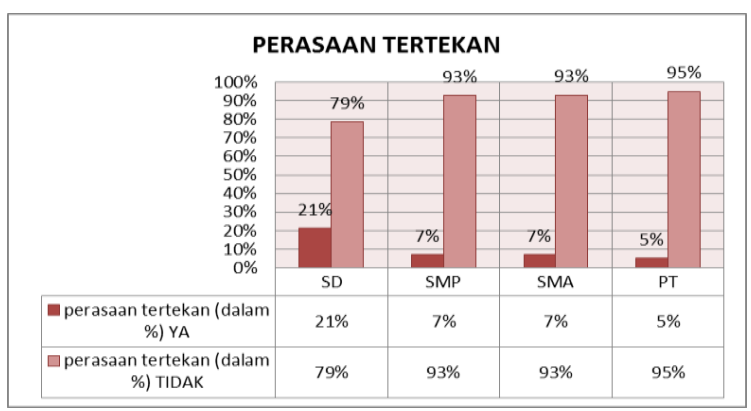

Gambar 4.

PerasaanTertekan

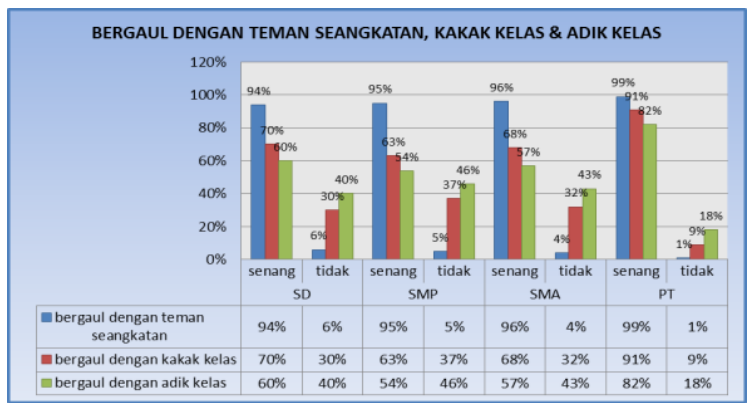

Gambar 5.

Pergaulan dengan Teman Seangkatan, Kakak Kelas dan Adik Kelas 
Pertanyaan selanjutnya adalah pergaulan dengan teman seangkatan, pergaulan dengan kakak kelas dan pergaulan dengan adik kelas. Berdasarkan hasil penelitian menunjukkan bahwa pergaulan dengan teman seangkatan menjadi hal yang menyenangkan bagi siswa di setiap level pendidikan. Sedangkan pergaulan dengan kakak kelas maupun dengan adik kelas menjadi hal yang kurang menyenangkan. Pergaulan dengan kakak kelas ataupun adik kelas menjadi kurang menyenangkan karena adanya perbedaan pendapat, sulit diajak komunikasi, dan sombong. Dari berbagai tingkat pendidikan, pada tingkat SMP prosentase siswa yang tidak senang bergaul dengan kakak kelas ataupun adik kelas paling tinggi.

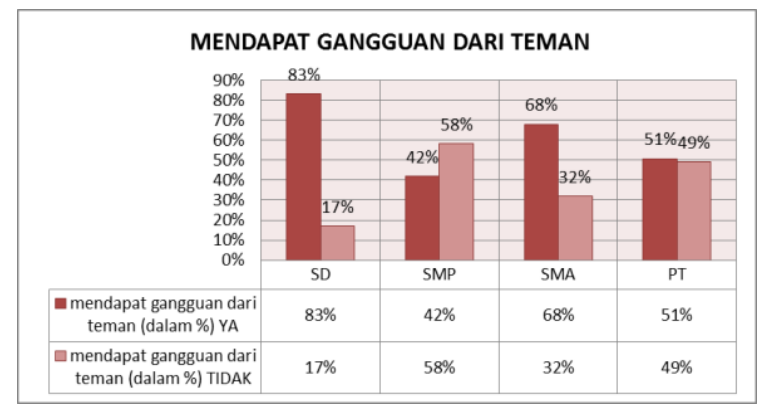

Gambar 6

Gangguan dari Teman

Pertayaan pertama yang berkaitan langsung dengan bullying adalah apakah subjek pernah mendapat gangguan dari teman. Berdasarkan data pada gambar 6 sebanyak $83 \%$ siswa SD pernah mendapatkan gangguan dari teman, siswa SMP sebanyak $42 \%$, siswa SMA sebanyak $68 \%$ dan mahasiswa $51 \%$.

Gangguan yang dialami para subjek lebih banyak berupa gangguan yang menghambat proses belajar di kelas/ di perkuliahan. Pada mahasiswa gangguan yang diterima yaitu teman yang berisik saat kuliah sehingga mengganggu konsentrasi dan diajak ngobrol ketika kuliah. Pada siswa SMA gangguan yang muncul berupa ramai di kelas saat jam pelajaran, ejekan dan olokan yang sifatnya bercanda, dan menggosip. Pada siswa SMP gangguan yang terjadi yaitu ramai saat jam pelajaran di kelas, dijahilin dan diajak ngobrol ketika jam pelajaran. Para siswa SD melaporkan mendapatkan gangguan teman berupa situasi yang gaduh ketika pelajaran dan dijahilin. Selain itu temuan menarik yang diperoleh dari siswa SD menunjukkan bahwa gangguan dari teman sudah mengarah pada bentuk bentuk kekerasan fisik yaitu memukul, mengancam, menggertak, mengejek, mencubit dan menjambak. Oleh karena itu dari berbagai tingkatan pendidikan, siswa SD melaporkan gangguan ini sebagai masalah yang serius, sedangkan di tingkat SMA masalah gangguan dari teman bukan menjadi masalah yang serius.

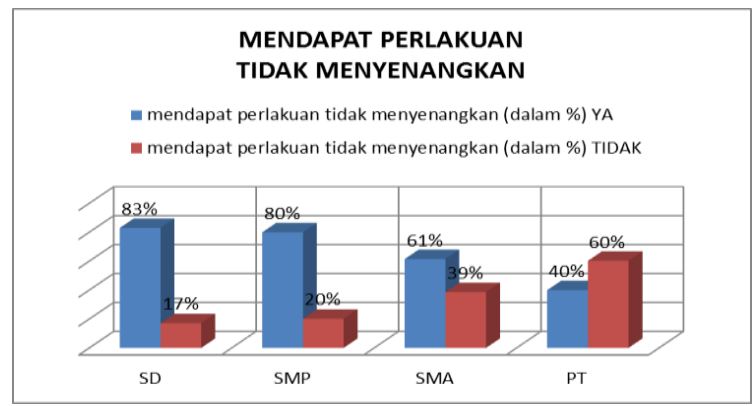

Gambar 7.

Mendapat Perlakuan Tidak Menyenangkan

Gambar 7 menunjukkan data tentang perlakuan tidak menyenangkan. Berbeda dengan gambar 6 tentang bentuk gangguan, perlakuan tidak menyenangkan ini sudah mengarah pada perilaku bullying.

Hasil penelitian ini menunjukkan bahwa pada tingkat SD sampai SMA subjek yang mendapat perlakuan tidak menyenangkan lebih tinggi prosentasenya daripada subjek yang tidak mendapat perlakuan tidak menyenangkan. Prosentasenya cukup tinggi sekitar $82 \%$ pada tingkat SD, 80\% pada tingkat SMP dan $60 \%$ pada tingkat SMA. Pada tingkat Perguruan Tinggi, prosentase subjek yang mendapat perlakuan tidak menyenangkan hanya $40 \%$. 
Berdasarkan data dari gambar 8 dapat disimpulkan bahwa prosentase subjek yang pernah menyakiti teman pada berbagai tingkat pendidikan cukup tinggi. Pada tingkat SMA prosentasenya paling tinggi, mencapai $70 \%$. Sedangkan prosentase terkecil terjadi pada tingkat perguruan tinggi.

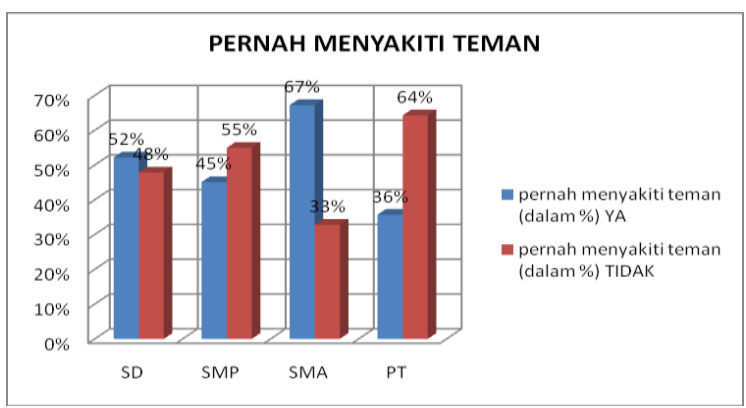

Gambar 8.

Menyakiti Teman

Bentuk-bentuk perilaku menyakiti teman yang muncul pada mahasiswa adalah menggunakan kata-kata kasar, labeling, mengolok-olok, mengejek dan membentak. Pada siswa SMA bentuk perilaku menyakiti teman yang muncul adalah mengejek, mengolok-olok, mengacuhkan, memukul, menyebarkan gosip dan mengirimkan Short Message Services (SMS) dengan kata-kata kasar. Pada siswa SMP tidak jauh berbeda, dimana perilaku menyakiti teman yang muncul yaitu mengejek, membentak, memukul dan mencubit. Pada siswa SD bentuk perilaku menyakiti teman yang muncul yaitu mengejek, mencubit, memukul, menjambak, menggosip dan mengambil barang secara paksa.

Perlakuan tidak menyenangkan yang diterima siswa sangat beragam. Berikut adalah penjelasan bentuk perilaku tidak menyenangkan pada setiap tingkat pendidikan. Pada tingkat SD, perlakuan tidak menyenangkan yang paling sering diterima adalah memanggil dengan nama julukan yang tidak disukai, sedangkan perlakuan tidak menyenangkan yang paling sedikit diterima adalah menolak berbicara.
Pada tingkat SMP, terdapat tiga jenis perlakuan tidak menyenangkan yang paling banyak diterima yaitu memanggil nama dengan julukan yang tidak disukai, diikuti menggoda hingga marah dan menyebarkan gosip. Sedangkan bentuk perlakuan tidak menyenangkan yang paling jarang diterima adalah menolak memasukkan dalam kelompok/per group.

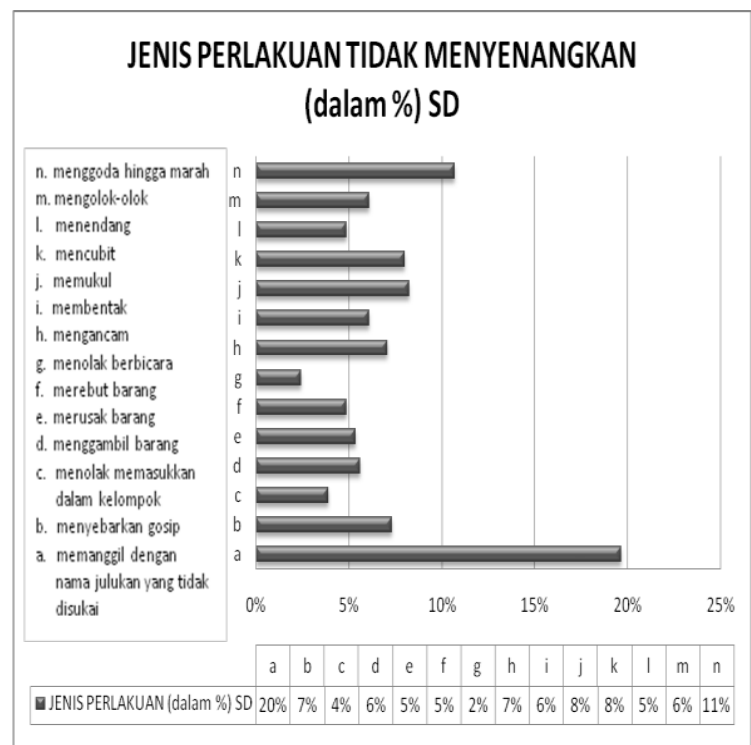

Gambar 9.

Perlakuan Tidak Menyenangkan Pada Tingkat SD

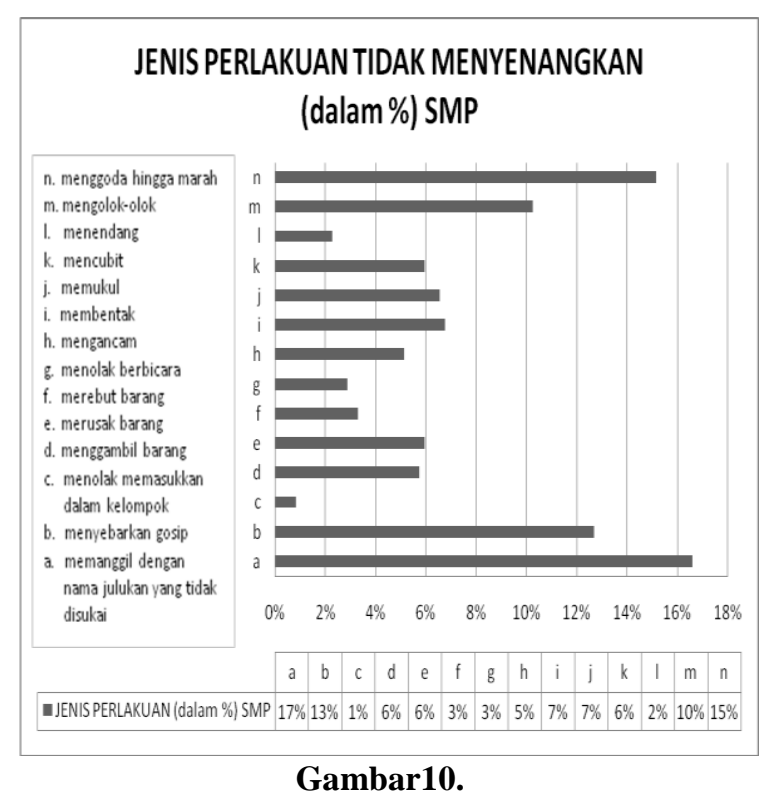

Perlakuan Tidak Menyenangkan Pada Tingkat SMP 


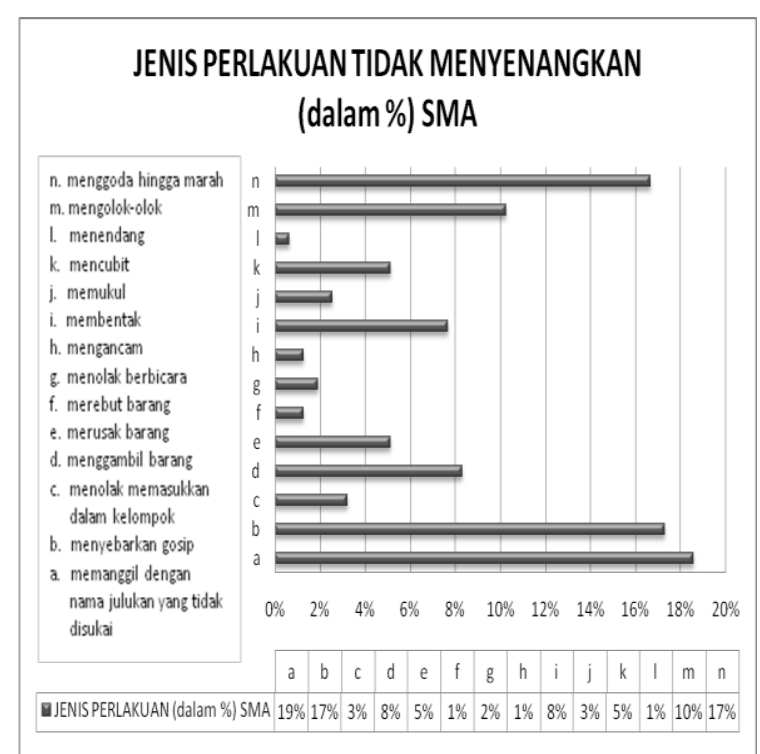

Gambar 11.

Perlakuan Tidak Menyenangkan Pada Tingkat SMA

Pada tingkat SMA, terdapat tiga bentuk perlakuan tidak menyenangkan yang paling banyak diterima yaitu memanggil dengan nama julukan yang tidak disukai, menyebarkan gosip dan menggoda hingga marah. Sedangkan bentuk perlakuan tidak menyenangkan yang paling jarang diterima adalah menendang.

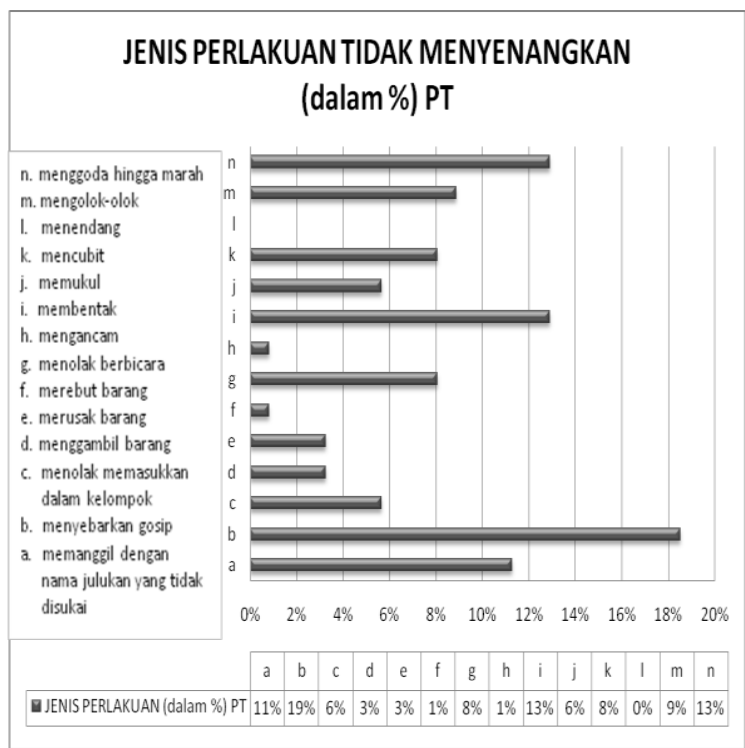

Gambar 12.

Perlakuan Tidak Menyenangkan Pada Tingkat PT

Pada tingkat Perguruan Tinggi, bentuk perlakuan tidak menyenangkan yang diterima lebih beragam. Bentuk perilaku tidak menyenangkan yang paling sering diterima adalah menyebarkan gosip. Bentuk perilaku tidak menyenangkan yang lainnya adalah membentak, menggoda hingga marah dan memanggil dengan nama julukan yang tidak disukai. Bentuk perlakuan tidak menyenangkan yang jarang diterima pada tingkatan ini adalah merebut barang dan mengancam.

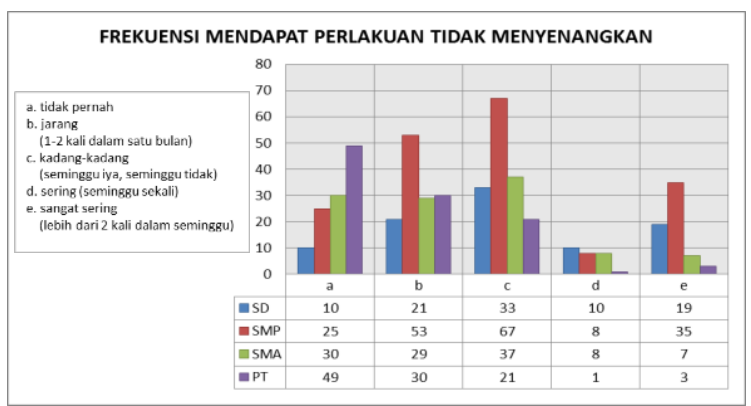

Gambar 13.

Frekuensi mendapat Perlakuan

Tidak Menyenangkan

Gambar 13 menunjukkan seberapa sering subjek mendapatkan perlakuan tidak menyenangkan. Berdasarkan gambar 13, dapat disimpulkan bahwa pada tingkat SD sampai SMA perlakuan tidak menyenangkan terjadi kadang-kadang saja dengan rentang waktu mingguan, sedangkan pada tingkat perguruan tinggi perlakuan tidak menyenangkan jarang diterima, hanya 1-2 kali dalam satu bulan.

Berdasarkan gambar 14 dapat disimpulkan bahwa pada berbagai tingkat pendidikan, perlakuan tidak menyenangkan paling sering terjadi saat istirahat/jeda kuliah. Prosentase paling tinggi terjadi pada tingkat perguruan tinggi, diikuti SMP dan SD. Sedangkan pada tingkat SMA, perlakuan tidak menyenangkan ini paling sering terjadi saat pelajaran di kelas.

Berdasarkan data pada Gambar 15, dapat disimpulkan bahwa pada berbagai tingkat pendidikan perlakuan tidak menyenangkan paling sering diterima di kelas/ ruang kuliah, dan halaman sekolah, dengan 
prosentase tertinggi terjadi pada tingkat SD. Sedangkan pada tingkat perguruan tinggi perlakuan tidak menyenangkan paling sering terjadi di kantin dan di luar kampus.

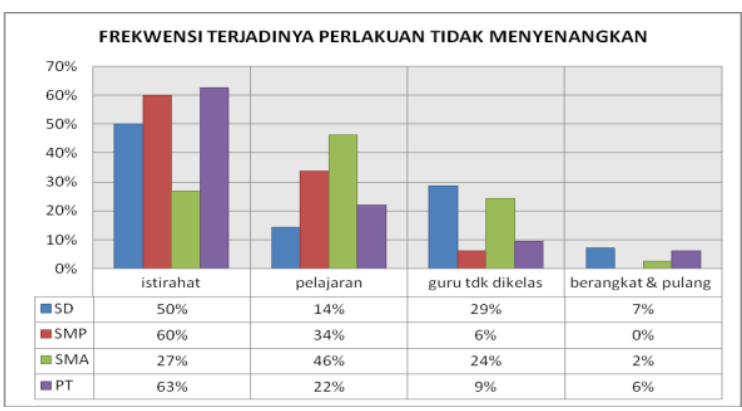

Gambar 14.

Waktu Terjadinya Perlakuan Tidak Menyenangkan

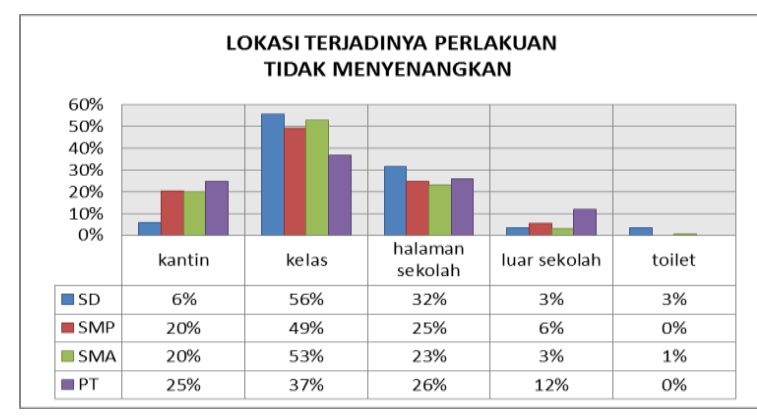

Gambar 15.

Lokasi terjadinya Perlakuan Tidak Menyenangkan

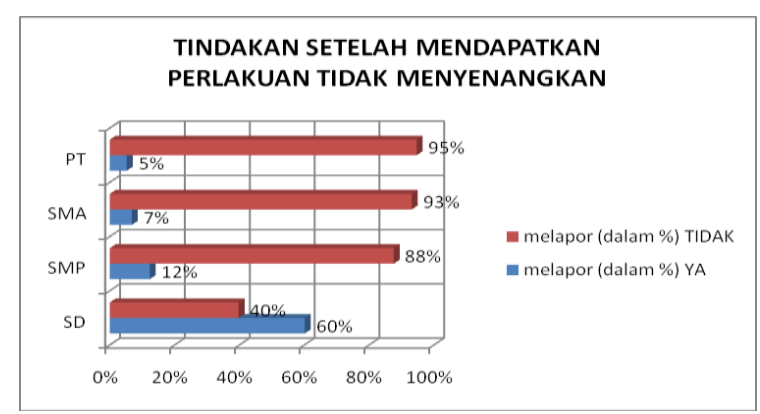

Gambar 16.

Tindakan Setelah Mendapat Perlakuan Tidak Menyenangkan

Berdasarkan Gambar 16 dapat disimpulkan bahwa sebagian besar subjek tidak melapor ketika mendapat perlakuan tidak menyenangkan. Diantara berbagai tingkat pendidikan, prosentase subjek yang melapor paling tinggi terjadi pada tingkat $\mathrm{SD}$, selanjutnya semakin tinggi tingkat pendidikan prosentase subjek yang melapor semakin menurun.

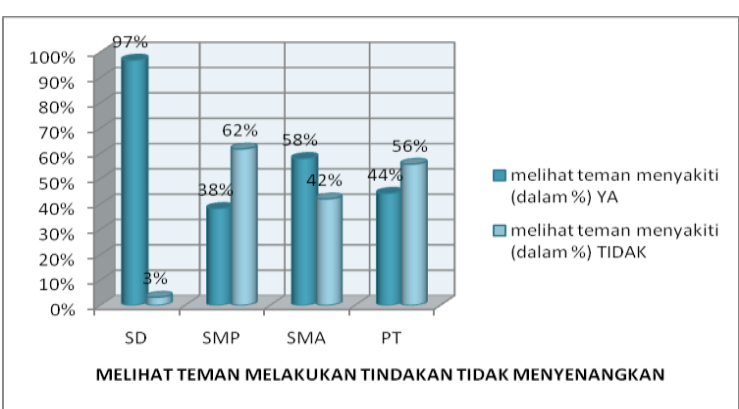

Gambar17.

Melihat Teman Menyakiti Teman Lain

Data pada Gambar 17 menunjukkan apakah subjek pernah melihat temannya menyakiti teman lainnya atau tidak. Berdasarkan data di atas dapat dilihat bahwa pada tingkat SD, sebagian besar subjek melihat teman yang menyakiti teman lainnya. Pada tingkat SMP dan perguruan tinggi prosentase subjek yang melihat teman menyakiti teman yang lain lebih rendah.

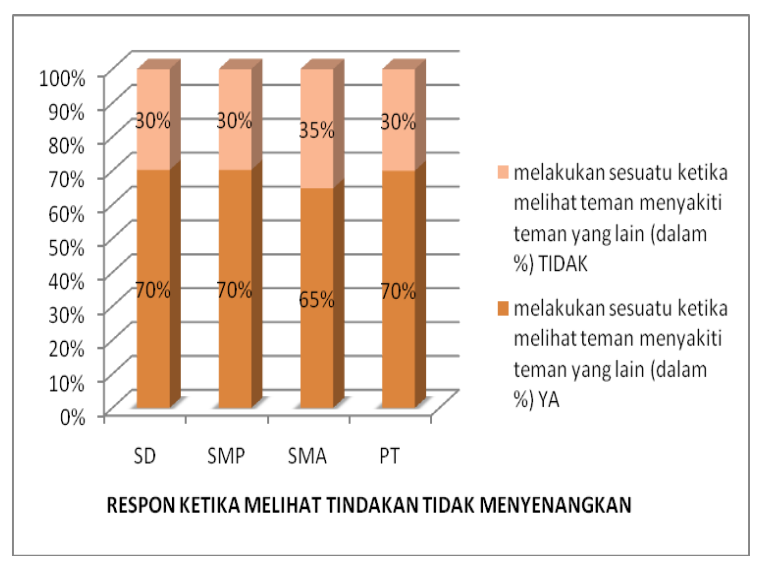

\section{Gambar 18}

Respon Ketika Melihat Perilaku Bullying

Data pada Gambar 18 menunjukkan respon subjek ketika melihat perilaku bullying. Berdasarkan data pada gambar 18 tersebut dapat dilihat bahwa pada semua tingkat pendidikan, sebagian besar subjek melakukan sesuatu ketika melihat bullying yang menimpa temannya. Pada mahasiswa tindakan yang dilakukan adalah membela korban, menolong korban, mengingatkan 
pelaku, menegur, melerai, mengingatkan bahwa itu tidak baik. Pada siswa SMA tindakan yang dilakukan adalah menolong, membela dan menghibur korban, melerai, menasihati, menegur dan mengingatkan pelaku. Pada siswa SMP tindakan yang dilakukan adalah menolong, membela dan menenangkan korban, melerai dan memarahi pelaku. Sedangkan pada siswa SD perilaku yang ditunjukkan ketika mengetahui ada bullying yang menimpa temannya adalah menolong dan membela korban, melerai, menasihati dan melapor pada guru.

\section{KESIMPULAN}

Berdasarkan hasil analisis data dapat disimpulkan bahwa sebagian besar siswa pada semua tingkat pendidikan pernah medapatkan gangguan dari teman. Siswa yang paling banyak mendapat gangguan adalah siswa SD. Sebagian besar siswa pada semua tingkat pendidikan tidak menganggap gangguan ini sebagai masalah serius.

Sesuatu yang membuat takut dan sedih, marah, tertekan di sekolah paling sering terjadi pada siswa SD Sebagian besar siswa pada semua tingkat pendidikan pernah mendapat perlakuan tidak menyenangkan. Bentuk perlakuan tidak menyenangkan yang paling sering diterima pada semua tingkat pendidikan adalah memanggil dengan nama julukan yang tidak disukai. Semakin tinggi tingkat pendidikan ada penambahan bentuk perlakuan tidak menyenangkan yaitu dengan menyebarkan gosip. Perlakuan tidak menyenangkan terjadi kadang-kadang, dengan rentang waktu mingguan. Perlakuan tidak menyenangkan paling sering terjadi saat istirahat/jeda kuliah. Perlakuan tidak menyenangkan paling sering diterima di kelas/ ruang kuliah, dan halaman sekolah, dengan prosentase tertinggi terjadi pada tingkat SD. Sedangkan pada tingkat perguruan tinggi perlakuan tidak menyenangkan paling sering terjadi di kantin dan di luar kampus.

Siswa yang melapor paling tinggi terjadi pada tingkat SD, selanjutnya semakin tinggi tingkat pendidikan prosentase subjek yang melapor semakin menurun. Pada semua tingkat pendidikan, sebagian besar subjek melakukan sesuatu ketika melihat bullying yang menimpa temannya. Prosentase subjek yang pernah menyakiti teman pada berbagai tingkat pendidikan cukup tinggi. Pada tingkat SMA prosentasenya paling tinggi, mencapai $70 \%$.

\section{DAFTAR PUSTAKA}

Bernard, M. E., \& Milne, M. L. (2008). School procedures and practices for responding to students who bully. $A$ Report for Victorian Department of Education and Early Childhood Development. Retrieved September 10, 2008 from: http://www.eduweb. vic.gov.au/edulibrary/public/stuman/ wellbeing/responding_to_student_wh o_Bully-may_2008.pdf.

Carney, A. G., \& Merrel, K. W. (2001). Bullying in schools: Perspectives on understanding and preventing an international problem. School Psychology International , 22, 364-379.

Craig, W. M., Henderson, K., \& Murphy,J. G. (2000). Prospective teachers attitudes toward bullying and victimization. School Psychology International , 21, 5-23.

Craig, W. M., Pepler, D.J., \& Blais, J. (2007). Responding to bullying: What works? School Psychology International, 28, 465-477.

Fekkes, M., Pijpers, F.I.M., VerlooveVanhorick, S. P. (2005). Bullying: 
who does what, when and where? Invotment of children, teachers, and parents in bullying behavior. Health Education Research, 20,81-91

Holt, K. M. (2004). A Premier On Bullying. Crimes against children research center. Retrived from www.chhs. unh.edu/sites/chhs.unh.edu/files/doc s/fs/adolescent.resources/Bullying.p df
Olweus, D. (1993). Bullying at school: What we know and what we can do. Oxford: Blackwell.

Rigby, K. (2002). New prepectives of Bullying. London: Jessica Kingsley Publishers Ltd 